\title{
Chemical control of California arrowhead (Sagittaria montevidensis) resistant to acetolactate synthase and photosystem II inhibiting herbicides in irrigated rice
}

\author{
Manejo químico de sagitária (Sagittaria montevidensis) resistente aos herbicidas inibidores de \\ Acetolactato Sintase e Fotossistema II aplicados em arroz irrigado
}

\author{
Diogo da Silva Moura' José Alberto Noldin ${ }^{\text {II }}$ Leandro Galon ${ }^{\text {III }}$ \\ Diogo Balbé Helgueira ${ }^{\mathrm{I}}$ Karen Piraine Martins $^{\mathrm{IV}}$ Luciano Luis Cassol ${ }^{\mathrm{IV}}$
}

\section{ABSTRACT}

California arrowhead is one of the primary weeds infesting paddy rice fields in the Brazilian states of Santa Catarina and Rio Grande do Sul, where the system of pre-germinated seeding is used. The objective of this study was to evaluate the selectivity and effectiveness of saflufenacil application in irrigated rice, either singly or in combination with other herbicides in the same application or sequentially, for the control of Sagittaria montevidensis biotype that is resistant to ALSand PSII-inhibiting herbicides. In the first experiment carried out in a greenhouse, saflufenacil was applied, either singly or in combination with penoxsulam, bispyribac-sodium, pyrazosulfuron-ethyl, bentazon, or propanil to the S. montevidensis (SAGMO 32) biotype and the irrigated rice variety Epagri 108. In the second experiment, single or combined (including sequential) applications of saflufenacil, bentazon, and cyhalofop-butyl were applied to Epagri 108 in open field conditions. Saflufenacil combined with propanil showed a high degree of phytotoxicity and a reduction in the accumulation of dry mass in Epagri 108. Application of saflufenacil, bentazon, and cyhalofop-butyl in combination or sequentially resulted in an increase in phytotoxicity in Epagri 108 compared to when applied singly. A pplication of saflufenacil singly or in combination with penoxsulam, bispyribac-sodium, bentazon, or pyrazosulfuron-ethyl did not adequately control SAGMO 32.

Key words: Oryza sativa, Sagitaria, multiple resistance.

RESUMO

A sagitária tem sido considerada uma das principais plantas daninhas infestante das áreas orizicolas de Santa Catarina e do Rio Grande do Sul que utilizam o sistema de semeadura pré- germinado. Objetivou-se com o trabalho avaliar a seletividade e a eficácia da aplicação de saflufenacil em isolado, em mistura e/ ou de forma sequencial com outros herbicidas em arroz irrigado, para o manejo de biótipos de Sagittaria montevidensis resistente aos herbicidas inibidores de ALS e FSII. O primeiro experimento, realizado em casa de vegetação, foi composto de aplicações de safufenacil, de modo isolado ou combinado com penoxsulam, bispyribac-sodium, pyrazosulfuron-ethyl, bentazon ou propanil sobre o biótipo de S. montevidensis (SAGMO 32) e da cultivar de arroz irrigado Epagri 108. No segundo experimento, avaliaramse, em condições de campo, aplicações isoladas, combinadas e sequencial de saflufenacil, bentazon e cyhalofop-butyl sobre a cultivar Epagri 108. O saflufenacil combinado com propanil apresenta elevada fitotoxicidade e redução do acúmulo de massa seca da cultivar Epagri 108. A aplicação de forma combinada ou sequencial de saflufenacil, bentazon e cyhalofop-butyl ocasiona aumento da fitotoxicidade à cultivar Epagri 108 em comparação àaplicação isolada. A aplicação isolada de saflufenacil ou combinada com penoxsulam, bispyribac-sodium, bentazon ou pyrazosulfuron-ethyl não proporcionou controle adequado do SAGMO 32.

Palavras-chave: Oryza sativa, sagitaria, resistência múltipla.

\section{INTRODUCTION}

California

arrowhead

(Sagittaria montevidensis Cham. \& Schlecht.) is one of the primary weeds infesting paddy rice fields in the Brazilian states of Santa Catarina (SC) and Rio

\footnotetext{
IPrograma de Pós-graduação em Fitossanidade, Faculdade de Agronomia Eliseu Maciel (FAEM), Universidade Federal de Pelotas (UFPel), Capão do Leão, RS, Brasil.

IEmpresa de Pesquisa Agropecuária e Extensão Rural de Santa Catarina (Epagri), Estação Experimental de Itajaí, Itajaí, SC, Brasil.

IIIPrograma de Pós-graduação em Ciência e Tecnologia Ambiental, Universidade Federal da Fronteira Sul (UFFS), Câmpus Erechim, 99700-970, Erechim, RS, Brasil. E-mail: leandro.galon@uffs.edu.br. Corresponding author.

IV Faculdade de Agronomia Eliseu Maciel (FAEM), Universidade Federal de Pelotas (UFPel), Capão do Leão, RS, Brasil. Received 02.05.16 Approved 06.29.16 Returned by the author 09.26.16 CR-2016-0117.R1
} 
Grande do Sul (RS), where the system of pregerminated seeding is used (CASSOL et al., 2008). Chemical control has been widely used in SC for the control of $\boldsymbol{S}$. montevidensis, with at least one herbicide application during the rice crop season.

The use of herbicides at non-recommended rates and/or not practicing rotation in control methods has increased the selection pressure and, consequently, an increase in resistant weed-infested crops. Various S. montevidensis biotypes have been shown to be resistant to acetolactate synthase (ALS)-inhibiting herbicides (MEROTTO JR. et al., 2010; MOURA et al., 2015). Resistance to photosystem II (PSII) herbicides has also been shown (MOURA et al., 2015). Currently, S. montevidensis biotypes show multiple resistance, in other words, resistance to both ALSand PSII-inhibiting herbicides (MOURA et al., 2015). An alternative way of controlling $\boldsymbol{S}$. montevidensis is through the use of herbicides combination, broadening the spectrum of action and reducing the number of applications necessary; thereby, reducing the cost of production (PETTER et al., 2012).

The objective of this study was to evaluate the selectivity and effectiveness of saflufenacil application in irrigated rice, either singly or in combination with other herbicides in the same application or sequentially, for the control of Sagittaria montevidensis biotypes resistant to ALSand PSII-inhibiting herbicides.

\section{MATERIALS AND METHODS}

Two experiments (I and II) were conducted during the 2012/13 (experiment I) and 2013/14 (experiment II) growing seasons. In both experiments, field soil (Hydromorphic Eutrophic solodic Planosol) was used as a substrate. The experimental design was fully randomized with four replications.

To perform the experiments, the Epagri 108 rice variety was used along with a biotype of S. montevidensis (SAGMO 32) that has multiple resistance to ALS- and PSII-inhibiting herbicides (as shown in previous studies) and was collected from rice fields in Ilhota county, SC.

Experiment I was conducted in a greenhouse at the Faculdade de Agronômia Eliseu Maciel (FAEM)/Universidade Federal de Pelotas (UFPel), Capão do Leão, RS. Experimental units comprised plastic pots filled with $5 \mathrm{~kg}$ of soil. Treatments for experiment 1 were as follows: saflufenacil $\left(100 \mathrm{~g}\right.$ a.i. ha $\left.{ }^{-1}\right)$, saflufenacil $\left(100 \mathrm{~g}\right.$ a.i. ha $\left.{ }^{-1}\right)$ + Dash $\mathrm{HC}^{\circledR}(0.5 \% \mathrm{v} / \mathrm{v})$, saflufenacil (100g a.i. ha $\left.{ }^{-1}\right)$ $+\operatorname{penoxsulam}\left(60 \mathrm{~g}\right.$ a.i. ha $\left.{ }^{-1}\right)+$ Veget'Oil $^{\circledR}(0.5 \% \mathrm{v} / \mathrm{v})$, saflufenacil $\left(100 \mathrm{~g}\right.$ a.i. ha $\left.{ }^{-1}\right)+$ bispyribac-sodium $(50 \mathrm{~g}$ a.i. ha $\left.{ }^{-1}\right)+$ Iharaguen- $\mathrm{S}^{\circledR}(0.25 \% \mathrm{v} / \mathrm{v})$, saflufenacil $\left(100 \mathrm{~g}\right.$ a.i. ha $\left.{ }^{-1}\right)+$ pyrazosulfuron-ethyl $\left(20 \mathrm{~g}\right.$ a.i. ha $\left.{ }^{-1}\right)$, saflufenacil $\left(100 \mathrm{~g}\right.$ a.i. ha $\left.{ }^{-1}\right)+$ bentazon $(960 \mathrm{~g}$ a.i. ha $\left.^{-1}\right)+\operatorname{Assist}^{\circledR}\left(1 \mathrm{~L} \mathrm{ha}{ }^{-1}\right)$, saflufenacil $\left(100 \mathrm{~g}\right.$ a.i. ha $\left.{ }^{-1}\right)$ + propanil $\left(3660 \mathrm{~g}\right.$ a.i. $\left.\mathrm{ha}^{-1}\right)$ and a control without herbicide. Herbicide treatments were applied to the S. montevidensis biotype and Epagri 108 rice plants.

For the experiment II, the experimental units comprised plastic pots filled with $4 \mathrm{~kg}$ of soil that placed in an open area in the Centro Agropecuário de 'Palma (CAP), at the Universidade Federal de Pelotas. Treatments within experiment 2 were as follows: saflufenacil $\left(147 \mathrm{~g}\right.$ a.i. ha $\left.{ }^{-1}\right)+$ Dash $\mathrm{HC}^{\circledR}$ $(0.5 \% \mathrm{v} / \mathrm{v})$, bentazon $\left(960 \mathrm{~g}\right.$ a.i. ha $\left.{ }^{-1}\right)+\operatorname{Assist}^{\circledR}(0.5 \%$ v/v), cyhalofop-butyl (315g a.i. ha $\left.{ }^{-1}\right)+$ Veget'Oil $^{\circledR}$ $\left(1 \mathrm{~L} \mathrm{ha} \mathrm{ha}^{-1}\right)$, bentazon $\left(960 \mathrm{~g}\right.$ a.i. ha $\left.{ }^{1}\right)+$ saflufenacil $\left(147 \mathrm{~g}\right.$ a.i. ha $\left.{ }^{-1}\right)+\operatorname{Dash} \operatorname{HC}^{\circledR}(0.5 \% \mathrm{v} / \mathrm{v})$, bentazon $\left(960 \mathrm{~g}\right.$ a.i. ha $\left.{ }^{-1}\right)+$ Assist $^{\circledR}(0.5 \% \mathrm{v} / \mathrm{v})+$ saflufenacil

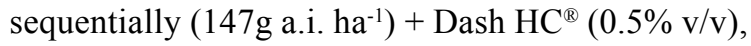
cyhalofop-butyl $\left(315 \mathrm{~g}\right.$ a.i. ha $\left.{ }^{-1}\right)+$ saflufenacil $(147 \mathrm{~g}$ a.i. ha $\left.{ }^{-1}\right)+$ Veget'Oil $^{\circledR}\left(1 \mathrm{~L} \mathrm{ha}{ }^{-1}\right)$, cyhalofop-butyl $\left(315 \mathrm{~g}\right.$ a.i. ha $\left.{ }^{-1}\right)+$ Veget'Oil $^{\circledR}\left(1 \mathrm{~L} \mathrm{ha}^{-1}\right)+$ saflufenacil

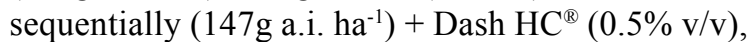
bentazon (960ga.i. ha $\left.{ }^{-1}\right)+$ cyhalofop-butyl (315g a.i. ha $\left.{ }^{-1}\right)+$ saflufenacil $\left(147 \mathrm{~g}\right.$ a.i. ha $\left.^{-1}\right)+$ Veget'Oil $^{\circledR}$ $\left(1 \mathrm{~L} \mathrm{ha}^{-1}\right)$ and a control without herbicide. Herbicide treatments were applied to the irrigated rice variety Epagri 108 with sequential applications carried out 24 hours after the initial application.

For experiment I, 40 seeds of $\boldsymbol{S}$. montevidensis biotype or 10 Epagri 108 seeds were sown in each experimental unit. For experiment II, only 10 seeds of Epagri 108 were sown in each experimental unit.

Soon after sowing, the pots were flooded to a level of $5 \mathrm{~cm}$ that was maintained for the entire experiment. In the experimental units sown with rice, irrigation was carried out whenever required. The plants were thinned prior to the application of herbicide, keeping five or six $\boldsymbol{S}$. montevidensis or rice plants per experimental unit for experiments 1 and 2, respectively. Furthermore, the water level was removed from the pots prior to herbicide application.

For the treatments composed of a combination of herbicides, the herbicides were mixed in the spraying tank to ensure a homogeneous solution. Afterwards, the herbicides were applied using a backpack sprayer pressurized by $\mathrm{CO}_{2}$ in which the spray boom had four flat fan nozzles, series 110.02 , spaced at $50 \mathrm{~cm}$ intervals, calibrated to apply the solution at a volume of $150 \mathrm{~L} \mathrm{ha} \mathrm{h}^{-1}$. Herbicides were applied when $\boldsymbol{S}$. montevidensis plants were 
10 to $15 \mathrm{~cm}$ high, with only lanceolate leaves, and rice plants at three to four leaves stage $\left(\mathrm{V}_{3}\right.$ to $\left.\mathrm{V}_{4}\right)$ (COUNCE et al., 2000).

Variables evaluated were the degree of S. montevidensis control and the phytotoxicity of the rice at seven, 14, 21, and 28 days after herbicide application (DAT). Control rating (\%) were attributed from 0 to 100 , where 0 corresponded to no sign of harm and 100 toplants death. The shoot dry biomass $\boldsymbol{S}$. montevidensis and rice at 28 DAT was also assessed. This was achieved by placing the collected vegetable matter in a dryer at $60^{\circ} \mathrm{C}$ until the biomass weight remained constant. The data obtained were analyzed to homoscedasticity and normality, with a $Y t=\arcsin$ $(y=0.5) / 100$ conversion in instances where the distribution did not present as normal. Following this, the data were subjected to analysis of variance using the F-test. If seen as significant, the treatments were compared using the Tukey's test to $5 \%$ probability.

\section{RESULTS AND DISCUSSION}

Experiment I: The variables evaluated were $\boldsymbol{S}$. montevidensis control and dry shoot biomass, rice injury and rice shoot dry biomass. There was, statistical significance for all treatments. Regarding to $\boldsymbol{S}$. montevidensis control at seven days after herbicide application (DAH), the combination of saflufenacil + propanil showed the greatest efficacy, and did not differ statistically from the combinations of saflufenacil + bispyribac-sodium, saflufenacil + bentazon, or saflufenacil + pyrazosulfuron-ethyl (Table
1). At $14 \mathrm{DAH}$, again, the higherpercentage of $\boldsymbol{S}$. montevidensis control (above 80\%), was obtained with the combination of saflufenacil + propanil,; although, this did not differ from the combination of saflufenacil + pyrazosulfuron-ethyl, saflufenacil + penoxsulam, or saflufenacil + bispyribac-sodium (Table 1).

These results were not sustained up to $28 \mathrm{DAH}$, where a pronounced reduction in the degree of control was observed. Combination of saflufenacil + propanil presented the higher control percentage at 21 and $28 \mathrm{DAH}$, differing significantly from other treatments.

In general, the combination of saflufenacil with herbicides that have alternative mechanisms of action improved $\boldsymbol{S}$. montevidensis control of biotype with resistance to ALS- and PSII-inhibitors. Combination of saflufenacil + bentazon provided $78.75 \%$ control of the multiple resistant population of $\boldsymbol{S}$. montevidensis at 7 DAH. This result is similar to that observed by MOURA et al. (2015) for the same biotype.

With regard to the rice selectivity of saflufenacil and its combination with other herbicides on the Epagri 108, variable levels of phytotoxicity were observed (Table 2). In general, the combination of saflufenacil + propanil presented higher levels of rice injury during all evaluation periods, which differed significantly from the other combinations, with the exception of saflufenacil + bispyribacsodium + Iharaguen-S ${ }^{\circledR}$ at 28 DAH. Results showed that for the majority of the treatments, at $28 \mathrm{DAH}$, the rice plants showed significant recovery from the harm caused by the herbicides, with the exception of

Table 1 - Control (\%) of ALS and Photosystem II inhibiting herbicide resistant Sagittaria montevidensis. Experiment I, Capão do Leão, RS, 2013.

\begin{tabular}{|c|c|c|c|c|c|c|c|}
\hline \multirow{3}{*}{$\begin{array}{l}\text { Treatments } \\
\text { Saflufenacil }\end{array}$} & \multirow{2}{*}{$7 \mathrm{DAH}^{1}$} & 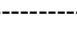 & & $1(\%)--$ & & & \\
\hline & & \multicolumn{2}{|c|}{14 DAH } & \multicolumn{2}{|c|}{$21 \mathrm{DAH}$} & \multicolumn{2}{|c|}{$28 \mathrm{DAH}$} \\
\hline & $71.25 \mathrm{~b}^{*}$ & 31.25 & $\mathrm{c}$ & 8.75 & $\mathrm{~b}$ & 3.75 & $\mathrm{bc}$ \\
\hline Saflufenacil + Dash $H^{\circledR}$ & $73.75 \mathrm{~b}$ & 55.00 & $\mathrm{bc}$ & 13.75 & $\mathrm{~b}$ & 7.50 & $\mathrm{~b}$ \\
\hline Saflufenacil + penoxsulam + Veget'Oil $^{\circledR}$ & $73.75 \mathrm{~b}$ & 67.50 & $a b$ & 12.50 & $\mathrm{~b}$ & 5.00 & $\mathrm{~b}$ \\
\hline Saflufenacil + bispyribac-sodium + Iharaguen- $S^{\circledR}$ & $78.75 \mathrm{ab}$ & 67.50 & $a b$ & 11.25 & $\mathrm{~b}$ & 6.25 & $\mathrm{~b}$ \\
\hline Saflufenacil + pyrazosulfuron-ethyl & $77.50 \mathrm{ab}$ & 71.25 & $a b$ & 7.50 & $\mathrm{~b}$ & 2.50 & bc \\
\hline Saflufenacil + bentazon + Assist ${ }^{\circledR}$ & $78.75 \mathrm{ab}$ & 51.25 & bc & 6.25 & $\mathrm{~b}$ & 3.75 & bc \\
\hline Saflufenacil + propanil & $91.75 \mathrm{a}$ & 83.75 & $\mathrm{a}$ & 52,50 & a & 36.25 & A \\
\hline Check & $0.00 \mathrm{c}$ & 0.00 & $\mathrm{~d}$ & 0.00 & $\mathrm{c}$ & 0.00 & $\mathrm{C}$ \\
\hline -----------------------------------CV (\%)------------- & 9.75 & 15.66 & & 22.67 & & 27.95 & \\
\hline
\end{tabular}

${ }^{1}$ DAH: Days after herbicide application. *Averages followed by different letters in the column differ among themselves using the Tukey's test to $5 \%$ probability. 
Table 2 - Phytotoxicity (\%) in irrigated rice variety Epagri 108. Experiment I, Capão do Leão, RS, 2013.

\begin{tabular}{|c|c|c|c|c|c|c|c|c|}
\hline \multirow{3}{*}{$\begin{array}{l}\text { Treatments } \\
\text { Saflufenacil }\end{array}$} & \multicolumn{8}{|c|}{ 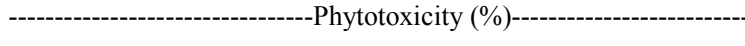 } \\
\hline & \multicolumn{2}{|c|}{$7 \mathrm{DAH}^{1}$} & \multicolumn{2}{|c|}{$14 \mathrm{DAH}$} & \multicolumn{2}{|c|}{$21 \mathrm{DAH}$} & \multicolumn{2}{|c|}{$28 \mathrm{DAH}$} \\
\hline & 25.00 & $\mathrm{~cd}^{*}$ & 20.00 & $\mathrm{~cd}$ & 12.50 & $\mathrm{c}$ & 10.00 & B \\
\hline Saflufenacil + Dash $\mathrm{HC}^{\circledR}$ & 41.25 & $\mathrm{~b}$ & 31.25 & $\mathrm{c}$ & 30.00 & $\mathrm{~b}$ & 15.00 & $\mathrm{~B}$ \\
\hline Saflufenacil + penoxsulam + Veget'Oil $^{\circledR}$ & 40.00 & $\mathrm{~b}$ & 65.00 & $a b$ & 35.00 & $\mathrm{~b}$ & 16.25 & B \\
\hline Saflufenacil + bispyribac-sodium + Iharaguen-S $\mathrm{S}^{\circledR}$ & 35.00 & bc & 56.25 & $\mathrm{~b}$ & 37.50 & $\mathrm{~b}$ & 32.50 & $\mathrm{Ab}$ \\
\hline Saflufenacil + pyrazosulfuron-ethyl & 18.75 & $\mathrm{~d}$ & 15.00 & $\mathrm{~cd}$ & 12.50 & $\mathrm{c}$ & 6.25 & bc \\
\hline Saflufenacil + bentazon + Assist $^{\circledR}$ & 18.75 & $\mathrm{~d}$ & 8.75 & $\mathrm{~d}$ & 7.50 & $\mathrm{c}$ & 5.00 & $\mathrm{bc}$ \\
\hline Saflufenacil + propanil & 86.25 & $\mathrm{a}$ & 78.75 & $\mathrm{a}$ & 75.00 & $\mathrm{a}$ & 50.00 & $\mathrm{a}$ \\
\hline Check & 0.00 & e & 0.00 & $\mathrm{e}$ & 0.00 & $\mathrm{~d}$ & 0.00 & $\mathrm{c}$ \\
\hline 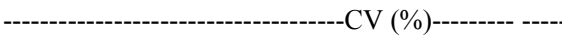 & 9.75 & & 15.18 & & 12.29 & & 24.09 & \\
\hline
\end{tabular}

${ }^{1} \mathrm{DAH}$ : Days after herbicide application. *Averages followed by different letters in the column differ among themselves using the Tukey's test to $5 \%$ probability.

saflufenacil + propanil. At 14 DAH, it was observed that the mixture of saflufenacil + penoxsulam + Veget'Oil presented similar phytotoxicity to that caused by saflufenacil + propanil. CAMARGO et al. (2011) reported similar results with the application of saflufenacil $\left(50 \mathrm{~g}\right.$ a.i. $\left.\mathrm{ha}^{-1}\right)+$ adjuvant. The same authors observed an initial phytotoxicity of $15 \%$ from this herbicide in rice plants at $8 \mathrm{DAH}$, decreasing to $3 \%$ at $24 \mathrm{DAT}$, and there was no reduction in grain yield.

At $28 \mathrm{DAH}$, the shoot dry biomass of $\boldsymbol{S}$. montevidensis was evaluated and reduction was observed in all treatments as compared with the control (Table 3). The results showed differences among the treatments with the combination of saflufenacil + propanil resulting in $90 \%$ reduction in dry mass of the $\boldsymbol{S}$. montevidensis. For the other treatments, there was no significant difference in the values obtained.

Rice shoot dry biomass revealed that the combination of saflufenacil + propanil caused greater harm to the plants, with a reduction of approximately $74 \%$, as compared to the control plants. The treatments with saflufenacil + pyrazosulfuron-ethyl and of saflufenacil + bentazon presented accumulations of shoot dry mass similar to the control treatment.

Based on these results, it can be stated that the application of different herbicide combinations is an important option for controlling multiple resistant S. montevidensis biotypes, because a reduction in dry mass accumulation will result in less competition for resources between the crop and the weed. However, rice producers must be aware about choosing the

Table 3 - Shoot dry biomass (\%) of Sagittaria montevidensis and rice at 28 days after herbicide application (DAH). Experiment I, Capão do Leão, RS, 2013.

\begin{tabular}{|c|c|c|}
\hline \multirow{2}{*}{ Treatments } & \multicolumn{2}{|c|}{-----------------Shoot dry biomass $(\%)^{1}---------------$} \\
\hline & SAGMO 32 & Rice \\
\hline Saflufenacil & 53.99 & 57.34 \\
\hline Saflufenacil + Dash $\mathrm{HC}^{\circledR}$ & 30.51 & 49.13 \\
\hline Saflufenacil + penoxsulam + Veget'Oil $^{\circledR}$ & 35.47 & 35.67 \\
\hline Saflufenacil + bispyribac-sodium + Iharaguen- $\mathrm{S}^{\circledR}$ & 38.26 & 50.02 \\
\hline Saflufenacil + pyrazosulfuron-ethyl & 39.56 & 73.97 \\
\hline Saflufenacil + bentazon + Assist $^{\circledR}$ & 49.66 & 75.15 \\
\hline Saflufenacil + propanil & 11.16 & 26.20 \\
\hline Check & $100.00 \quad \mathrm{a}$ & $100.00 \mathrm{a}$ \\
\hline 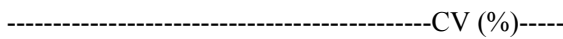 & 13.84 & 22.30 \\
\hline
\end{tabular}

${ }^{1}$ Percentage of the check $(=100 \%)$. ${ }^{*}$ Averages followed by different letters in the column differ among themselves using the Tukey's test to $5 \%$ probability.

Ciência Rural, v.46, n.12, dez, 2016. 
herbicides to be applied in order to avoid an increase in phytotoxicity, and; thus, it may affect rice yield.

In experiment II, for the variables rice phytotoxicity and dry mass, it was observed statistical significance of treatments. Different levels of phytotoxicity was observed in rice plants in all treatments during the evaluation period (Table 4).

In general, the application of bentazon + cyhalofop-butyl + saflufenacil + Veget'Oil ${ }^{\circledR}$, caused the highest phytotoxicity in the plants, reaching initial levels of more than $20 \%$, followed by a reduction to $8 \%$ during the last evaluation period. These results did not differ from applications of cyhalofop-butyl + saflufenacil + Veget'Oil ${ }^{\circledR}$ at 14 and $21 \mathrm{DAH}$, or from

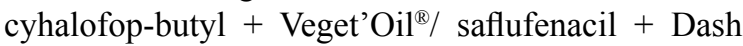
$\mathrm{HC}^{\circledR}$ at 21 and $28 \mathrm{DAH}$.

Combining herbicides in either the same application or sequentially, the levels of phytotoxicity to the plants were more than $10 \%$ during the first evaluation. These results represent an increase in rice injury compared to the single application that indicate the reduction of rice crop selectivity. The higher levels of phytotoxicity was observed when herbicides were applied in combinations, an outcome that continued to be seen until the final evaluation and also corresponded to a greater reduction in dry mass.

The application of bentazon + carfentrazone (a PROTOX inhibitor like saflufenacil) to the irrigated rice variety Epagri 108 caused phytotoxicity and a subsequent decrease in grain yield when compared to the application of saflifenacil alone (MENEZES et al., 2011). The combination of saflufenacil with other herbicides resulted in higher phytotoxicity to rice plantas, compared to the single application.; levels of phytotoxicity were higher with the combinations of saflufenacil + thiobencarb or clomazone (TAYLOR, 2010).

The treatment made up of bentazon + cyhalofop-butyl + saflufenacil + Veget'Oil ${ }^{\circledR}$ presented the highest reduction in shoot dry mass, $13 \%$ less than the control treatment, at $28 \mathrm{DAH}$. The application of bentazon + Assist $^{\circledR}$ presented an increase of $14.83 \%$ in dry mass, compared to the control.

Treatments that resulted in lower rice injury (less than 5\%) were bentazon + Assist $^{\circledR}$ and cyhalofopbutyl + Veget'Oil ${ }^{\circledR}$. These treatments caused either a non-significant reduction or an increase in dry mass, indicating that both may be used on the crop at the recommended rate without consequence to rice.

The similarity in the dry mass values obtained may be explained by the recovery the plants demonstrated to the effects caused by the herbicide application, whether combined or not. The fact that plants do not show reduction in shoot biomass from herbicide application is an important, given the aerial parts of the plant capture solar radiation, help in moisture retention and in lowering soil temperature variation through shading, and confer competitive capacity to the crop in respect to the space occupation.

\section{CONCLUSION}

Application of saflufenacil singly or in combination with penoxsulam, bispyribac-sodium, bentazon, or pyrazosulfuron-ethyl does not control

Table 4 - Phytotoxicity (\%) and shoot dry biomass (\%) of rice. Experiment II, Capão do Leão, RS, 2014.

\begin{tabular}{|c|c|c|c|c|c|c|c|c|c|c|}
\hline \multirow{3}{*}{$\begin{array}{l}\text { Treatments } \\
\text { Saflufenacil + Dash } \mathrm{HC}^{\circledR}\end{array}$} & \multicolumn{8}{|c|}{--'-10 } & \multirow{2}{*}{\multicolumn{2}{|c|}{$\begin{array}{l}\text { Shoot dry } \\
\text { biomass }(\%) 2\end{array}$}} \\
\hline & \multicolumn{2}{|c|}{$7 \mathrm{DAH}^{1}$} & \multicolumn{2}{|c|}{$14 \mathrm{DAH}$} & \multicolumn{2}{|c|}{$21 \mathrm{DAH}$} & \multicolumn{2}{|c|}{$28 \mathrm{DAH}$} & & \\
\hline & 6.25 & $\mathrm{~cd}^{*}$ & 5.00 & $\mathrm{c}$ & 0.50 & $\mathrm{C}$ & 0.00 & $\mathrm{~d}$ & 96.70 & abc \\
\hline Bentazon + Assist $^{\circledR}$ & 2.50 & de & 0.75 & $\mathrm{~d}$ & 0.50 & $\mathrm{C}$ & 0.00 & $\mathrm{~d}$ & 114.83 & a \\
\hline Cyhalofop-butyl + Veget'Oil ${ }^{\circledR}$ & 3.75 & de & 0.75 & $\mathrm{~d}$ & 0.00 & $\mathrm{C}$ & 0.00 & $\mathrm{~d}$ & 97.10 & $\mathrm{abc}$ \\
\hline Bentazon + saflufenacil + Dash $H^{\circledR}{ }^{\circledR}$ & 12.50 & bc & 8.50 & $\mathrm{bc}$ & 2.00 & $\mathrm{C}$ & 0.00 & $\mathrm{~d}$ & 94.03 & $\mathrm{bc}$ \\
\hline Bentazon + Assist $^{\circledR} /$ Saflufenacil + Dash $H^{\circledR}{ }^{\circledR}$ & 11.25 & bc & 10.75 & $\mathrm{~b}$ & 5.75 & $\mathrm{~B}$ & 1.25 & $\mathrm{~cd}$ & 100.18 & $\mathrm{ab}$ \\
\hline Cyhalofop-butyl + saflufenacil + Veget'Oil ${ }^{\circledR}$ & 16.25 & $\mathrm{~b}$ & 14.50 & $\mathrm{ab}$ & 7.00 & $\mathrm{Ab}$ & 3.50 & bc & 88.92 & bc \\
\hline Cyhalofop-butyl + Veget'Oil ${ }^{\circledR} /$ Saflufenacil + Dash HC $^{\circledR}$ & 16.25 & $\mathrm{~b}$ & 12.00 & $\mathrm{~b}$ & 8.25 & $\mathrm{Ab}$ & 5.75 & $\mathrm{ab}$ & 94.84 & $\mathrm{bc}$ \\
\hline Bentazon + cyhalofop-butyl + Saflufenacil + Veget'Oil $^{\circledR}$ & 28.75 & $\mathrm{a}$ & 22.50 & $\mathrm{a}$ & 12.50 & A & 8.00 & a & 87.06 & $\mathrm{c}$ \\
\hline Check & 0.00 & e & 0.00 & $\mathrm{~d}$ & 0.00 & $\mathrm{C}$ & 0,00 & $\mathrm{~d}$ & & \\
\hline 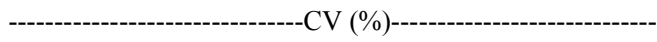 & 17.34 & & 15.17 & & 23.88 & & 25.48 & & 8.07 & \\
\hline
\end{tabular}

${ }^{1}$ DAH: Days after herbicide application. *Averages followed by different letters in the column differ among themselves using the Tukey's test to $5 \%$ probability. ${ }^{2}$ Values presented were compared to the check $(=100 \%)$. 
resistant S. montevidensis. Saflufenacil applied in combination with propanil showed increased phytotoxicity and reduced accumulation of dry mass in plants of Epagri 108 variety. Application of saflufenacil, bentazon, and cyhalofop-butyl applied singly resulted in low phytotoxicity to Epagri 108; however, when applied in combination or sequentially, an increase in phytotoxicity may occur and it may result in reduction of grain yield.

\section{REFERENCES}

CAMARGO, E.R. et al. Rice tolerance to saflufenacil in clomazone weed control program. International Journal of Agronomy, v.2011, n.1, p.1-8, 2011. Available from: $<$ http://www hindawi.com/journals/ija/2011/402461/>. Accessed: Jan. 15, 2015. doi: $10.1155 / 2011 / 402461$.

CASSOL, B. et al. Morphological analysis of Sagittaria montevidensis developed in different flood conditions. Planta Daninha, v.26, n.3, p.487-496, 2008. Available from: $<$ http://www. scielo.br/scielo.php?pid=S0100-83582008000300003>. Accessed: Jan. 15, 2015. doi: 10.1590/S0100-83582008000300003.

COUNCE, P. et al. A uniform, objective, and adaptive system for expressing rice development. Crop Science, v.40, n.2, p.436443, 2000.
MENEZES, V.G. et al. Controle de Sagittaria montevidensis (SAGMO) em áreas de arroz cultivadas no sistema prégerminado. In: CONGRESSO BRASILEIRO DE ARROZ IRRIGADO, 7,. 2011, Balneário Camburiú (SC). Anais... Itajaí (SC): Epagri, 2011. v.1, p.381-384

MEROTTO JR, A. et al. ALS gene isolation and investigation of herbicide resistance mechanism in Sagittaria montevidensis. Ciência Rural, v.40, n.11, p.2381-2384, 2010. Available from: <http://www.scielo. br/scielo.php?pid $=$ S $010384782010001100021 \& \mathrm{script}$ $=$ sci_arttext $>$. Accessed: Jan. 08, 2015. doi: 10.1590/ S010384782010005000183.

MOURA, D.S. et al. Multiple resistant biotypes of Sagittaria montevidensis to inhibiting acetolactate synthase and photosystem II herbicides. Planta Daninha, v.33, n.4, p.779-786, 2015. Available from: <http://dx.doi. org/10.1590/S0100-83582015000400016>. Accessed: Feb. 05,2016 .

PETTER, F.A. et al. Physical incompatibility of mixtures of herbicides and insecticides. Planta Daninha, v.30, n.2, p.449-457, 2012. Available from: $<$ http://www.scielo.br/scielo.php?pid=S0100$83582012000200025 \&$ script $=$ sci_arttext $>$. Accessed: Dec. 12, 2014. doi: 10.1590/S0100-83582012000200025.

TAYLOR, M.Weed management in australian rice production. Australia: Rural Industries Research and Development Corporation, Canberra, 2010. 65p. 